DOI: $10.2478 /$ rpp-2018-0011

Undergraduate Student, AADITYA RANJAN SRIVASTAVA

Mechanical Engineering Department, Integral University, Lucknow, Uttar Pradesh, India Address: Integral University, Kursi Road, Lucknow

Uttar Pradesh, India, 226024

E-mail: saadityaranjan@gmail.com

Doctoral Student, SHRISH BAJPAI

Electronics \& Communication Engineering Department, Dr. A.P.J. Abdul Kalam Technical University,

Lucknow, Uttar Pradesh, India

Address: Sector 11, JankipuramVistar, Lucknow, Uttar Pradesh, India E-mail: shrishbajpai@gmail.com

Bachelor of Technology (ECE), SUSHANT KHARE Executive, Tata Consultancy Services Limited, Bangalore Address: Tata Consultancy Services, Think Campus, Electronic Cit, Phase II, Bengaluru, Karnataka, 560100, India E-mail: khareysushant@gmail.com

\title{
CURRENT SCENARIO OF CERAMIC ENGINEERING EDUCATION IN INDIA
}

\begin{abstract}
Historical overview of ceramic development has been provided in the paper. It has been stated that the trail of ceramics has been rooted in Indus valley civilization. Advancement of materials leads to afflux of development in the fields of science and technology. Present paper deals with the realm of Ceramic Engineering, mainly focuses on education and jobs in the respected fields in India. This paper also holds the framework and research work in Ceramic Engineering in India. It has been defined that the whole processing of ceramics is done in the laboratories, like refractories, ceramics white wares, fuel furnace and pyrometry etc. There are a number of jobs which are offered by government sector as well as private sector. It has been determined that ceramic engineers are able to get job opportunities in aerospace, automotive industry, building material manufacturing, chemical industries, electronics, food processing, mining, medicine and refinery sectors in India. Curricula, undergraduate and postgraduate programs in Ceramics Engineering have been characterized. The peculiarities of dual degree education in Ceramics Engineering have been described. It has been stated that there are several initiatives taken by the government for the enhancement of skills and knowledge in Ceramics Engineering, which have been discussed in the extant paper. It has been defined that a new advancement in Ceramics Engineering is the initiative for enhancement of the knowledge through video lectures, offered by a couple of institutes. The prospects of ceramics application have been analyzed. It has been stated that the momentousness of ceramics are protruding diurnally just like in sculptures designing, pottery, building constructions, sanitary \& textile etc. Not only the designing field of ceramics but its use in
\end{abstract}


electronics field has been covered. It has been concluded that ceramic has a great potential to give solutions to the heat absorption between the walls or contacting surfaces. Earthenware was the heretofore product of ceramics. It has been proved that the future scope of ceramic is enormous. It has also been stressed that nowadays Ceramic Engineering is one of the emerging fields in engineering education, but a very prospective one.

Keywords: Ceramic Engineering, curriculum, engineering education in India, technical education, chemical processing, ceramic composites.

\section{INTRODUCTION}

Ceramic Engineering is one of the oldest disciplines of engineering which deals with the creation of inorganic and non-metallic solid material, which is produced by the technique of heat and cooling. Discovery of ceramics is one of the man's earliest achievements. The word "ceramic" originates from the Greek word "keramos" which means "burnt stuff". Ceramic Engineering is based on the principles of chemistry, physics and engineering. It is a junction of chemical engineering, material science and metallurgy engineering and physical sciences. The traces of ceramic industries have been found as early as 24000 B.C. in Czechoslovakia in the form of animals and human figurines, slabs and ball (Surendranathan, 2014). Potter's craft is one of the oldest vessels which are used in ancient times. The traces of ceramic products have been founded in Indus valley civilization around 2500 B.C. back in the form of clay pots. Gupta, Kushan, Shakas and Mughals played a great role in the development of Indian pottery. Ideals of Buddha were sent to Tibet, China, and Japan. Modern ceramic industry has been established by D. C. Majumdar at Gwalior. Painted sculptures were made with the use of ceramics in historical time. The descriptions of ceramics were also told in the Hindu mythology (Das, 2006).

The first product made with the use of ceramic was earthenware. The manufacturing process of ceramics includes clay and water, which is further mixed and casted into the desired shape, finally this mould passes through the furnace in which it is heated up to $1000-1600{ }^{\circ} \mathrm{C}$. As the time passes, innovation takes place and around 70006000 B.C. this ceramic material is used to fill the gap between stones for construction. When the advancement takes place humans start using ceramic for making vessels. During 4500-3500 B.C. white porcelain with bright blue glassy coating was composed. The first writing was in the form of symbols and pictures. The pictures and symbols were engraved on ceramic slab, walls etc. This gave the origin of pictograph and cuneiform symbol during 3500-2800 B.C. (Basu \& Balani, 2011).

THE AIM OF THE STUDY

Present study is aimed at the overview of the Ceramics Engineering in India specific to its education at the professional level. The authors outline two objectives of the present manuscript, which are as follows: 1) to give a complete review of the Ceramic Engineering education in India from diploma level to postdoctoral level; 2) to give a comparative overview of the job prospective related to the concerned field in India.

THEORETICAL FRAMEWORK AND RESERCH METHODS

Theoretical framework of present manuscript consists of current data on Ceramics Engineering education in India which were taken from the different institutions' websites. Only two technical institutes (in top fifty Indian institutes) - Indian Institute of TechnologyBanaras Hindu University and National Institute of Technology, Rourkela offer the degree programs in India having the separate department. Due to the importance of work, Indian Government is looking to revive this field of engineering. Similar type of study has been 
done by the Indian authors in the field of Biomedical Engineering, Control Engineering, Industrial Engineering, Manufacturing Engineering, Mechatronics, Mechanical Engineering, Production Engineering \& Renewable Energy (Bajpai \& Kidwai, 2017). Professional technical education in India is divided into five levels: diploma (polytechnic) education, undergraduate education, post graduation education, doctoral education \&postdoctoral education (Bajpai \& Akhtar, 2017).

Information about the running courses specific to the ceramic engineering is gathered from the websites of the Indian Institute of Technology and National Institute of Technology. Similar type of research has been done for the Control Engineering, Renewable Energy, Product Engineering, Manufacturing Engineering, Industrial Engineering.

\section{RESULTS}

In the four year curriculum of Ceramic Engineering in Indian Institute of Technology Banaras Hindu University (IIT-BHU, Varanasi) at undergraduate level 12-14 courses are run as basic sciences and introductory engineering subjects. There are 6-8 core subjects offered by other departments, 10-12 are core departmental subjects, 2 are open elective ones, 1 is a management subject, 4-6 are departmental elective subjects (Department of Ceramic Engineering, Indian Institute of Technology, 2018). Lab work is done in the field of glass and glass ceramics, refractories, advanced ceramics, ceramics white wares, fuel furnace and pyrometry, cement and concrete. UG curriculum also consists of a major project which is done in the final semester in fields of ceramic technology, material development program etc. The first year curriculum is common to the other branches which include the subjects of basic sciences, Introductory Engineering, and English. Second year curriculum includes the subject from material sciences, Mechanical Engineering and basic engineering sciences. A couple of subjects related to the ceramic raw material (including its properties) are offered by the department. Pre-final year is more focused on practical implementation subjects. They are related to process calculation, ceramic material characterization, refractories, glass engineering, electro ceramics and bioceramics. There are a few compulsory subjects offered in the final year which is related to the plant design, fuel furnace and pyrometry, cement, high temperature ceramic processes etc. The rest of the subjects are related to the departmental electives, open electives and management courses. Elective courses are divided into three major groups: Glass $\&$ glass ceramics, refractories and electro ceramic\& bioceramics. Students need to choose one of the groups which are nearly associated to their industrial training and undergraduate project.

Students, who opted dual degree in ceramic engineering, open elective and departmental elective undergraduate courses are free to choose dual degree eligible subjects instead of those core postgraduate subjects which are available to choose from (Bajpai et al., 2016). National Institute of Technology, Rourkela (NITR) offers postgraduate program of $M$. Tech with research - M. Tech (R). Major theoretical subjects covered under postgraduate program are Advanced Techniques for Material Characterization, Engineering Mathematics, Phase Equilibria \& Kinetics of Ceramic System etc. (Department of Ceramic Engineering, Indian Institute of Technology, 2018). There are also a couple of subjects which are offered as elective (Nano-Ceramics, Bio-Ceramics, Advanced Refractory Engineering, Advance Glass Technology, Cement Process Engineering etc.) in postgraduate program. The lab work is only in the first and second semester and the practical work is done in the field of Material Characterization, Plant Equipment \& Furnace Design Project, Electro ceramics\& Glass, Cement/Whiteware Refractories. In the last semester, students have to defend their disquisition in front of the audience, which includes an examiner. 
Areas for doctoral research are in the fields of Glass and Glass Ceramics, Refractories, Electrical and Electronic Ceramics, Cement and Advanced Building Materials, Bio-glass and Bio-Ceramics, Ceramic Synthesis and Processing Techniques and Composites. At doctoral level, several problem analyses in theoretical and practical fields are done. No institute in India offers postdoctoral degree in Ceramics.

Due to the nature of work, ceramic engineers are able to get the job opportunities in aerospace, automotive industry, building material manufacturing, chemical industries, electronics, food processing, mining, medicine and refinery sectors in India. Steel Authority of India Limited (SAIL), Central Electronics Limited (CEL), VIZAG Steel etc. are the major public sector units (PSU) that hired ceramic engineers for the particular dedicated job. Private companies, such as Kajaria Ceramics, Sadana, Euro Ceramics, Hindware, Asian Granito, Bajaj Tiles, Sonata Ceramics Asian paints are the major ceramic companies which hire ceramic engineers from the Institutions. A ceramic engineer can work as an administrator (project supervisor, technical consultant etc) and researcher in the companies or research institutes. Ceramic, fuel material, electronics ceramic, bio-ceramics; refractories are the current emerging areas in Ceramic Engineering. Tentative packages for ceramic engineers are 6 Lakhs to 10 Lakhs per annum.

S. Banerjee, M. Chatterjee, D. Ganguli, O. Gupta, S. Kumar, S. Sen, A. Surendranathan, A. Varshneya are the famous Indian authors who wrote the books on different topics of Ceramic Engineering. Common subjects related to Mechanical Engineering \& Material Science for ceramic undergraduates are the same as Mechanical Engineering undergraduates.

Indian Government has taken initiative for enhancement of the knowledge through video lectures (Akhtar et al., 2016). There are only two courses in NPTEL database and they are offered by Indian Institute of Technology, Kanpur and Indian Institute of Technology, Kharagpur. There are also courses offered in the fields of Electroceramics and Advanced Ceramics for Strategic Application. Students can access the video lecture through official video by providing login details. There are about nineteen to forty videos available which also include a weekly quiz. After completion of the course students get a certificate issued by NPTEL (Ananth, 2011).

\section{CONCLUSIONS}

Now days Ceramic Engineering is the one of the emerging fields in engineering education. Government of India has taken initiative for augmentation of knowledge (through NPTEL lectures) in the field of Ceramic Engineering. There is only a limited number of colleges in India that offer bachelor degree in Ceramic Engineering. Few colleges also offer specialization in the fields of Bioceramics, Nanoceramics, Glassceramics, and Advanced Ceramics etc. Depending on the application of ceramics, a number of jobs are soaring in the market which is one of the major factors for increasing employability in India. Ceramic is not only besmeared with material science engineering but also involved in aerospace industries, building $\&$ construction industries, electronics industries etc. In the research field of ceramics, the main focus is to ameliorate the properties of ceramic through different testing and processes, which is the direction of our further studies.

\section{REFERENCES}

1. Agarwal, P. (2007). Higher education in India: Growth, concerns and change agenda. Higher education quarterly, 61 (2), 197-207.

2. Akhtar, S., Iqbal, M., \& Bajpai, S. (2016). Control engineering as a part of 
undergraduate curriculum for mechanical engineering in India. Comparative professional pedagogy, 6 (3), 32-36.

3. Ananth, S. (2011). National programme on technology enhanced learning (NPTEL): The vision and the mission, Proceedings of Technology for Education International Conference. IEEE.

4. Bajpai, S., Asif, S., \& Akhtar, A. (2016). Electromagnetic education in India. Comparative professional pedagogy, 6 (2), 60-66.

5. Bajpai, S., \& Khare, S. (2015). Mechatronics engineering rducation in India. Comparative professional pedagogy, 5 (4), 73-79.

6. Bajpai, S., Khare, S., \& Yadav, R. (2016). Control education in India: present \& future. IFAC-PapersOnLine, 49 (1), 813-818.

7. Bajpai, S., \& Akhtar, S. (2017). Industrial engineering education in India. Comparative professional pedagogy, 7 (3), 84-92.

8. Bajpai, S., \& Kidwai, R. (2017). Renewable energy education in India. Comparative professional pedagogy, 7 (4), 103-113.

9. Basu, B., \& Balani, K. (2011). Advanced structural ceramics. New York, NY: John Wiley \& Sons.

10. Das, S. (2006). A study on the financial performance of Indian ceramic industry. Retrieved from http://shodhganga.inflibnet.ac.in/handle/10603/62349.

11. Department of Ceramic Engineering, Indian Institute of Technology (Banaras Hindu University) Varanasi. (2018). Syallbus of different degree programs. Retrieved from https://www.iitbhu.ac.in/cer/index.php/courses.html.

12. Dixit, S., Hazarika, M., \& Davim, P. (2017). A brief history of mechanical engineering. New York, NY: Springer.

13. Khare, S., Bajpai, S., \& Bharati, K. (2015). Production engineering education in India. Management and production engineering review, 6 (1), 21-25.

14. Khare, S., Chatterjee, A., Bajpai, S., \& Bharati, K. (2016). Manufacturing engineering education in India. Management and production engineering review, 7 (1), 40-44.

15. Khare, S., Chowdhry, S., \& Bajpai, S. (2014). Control engineering education in India, Proceedings of Power, Control and Embedded Systems (ICPCES) International Conference. IEEE.

16. Panda, K. (2016). Shodhganga - a national level open access ETD repository of Indian electronic theses: current status and discussions. Library Hi Tech News, 33 (1), 23-26.

17. Readey, W. (1985). Ceramic engineering education. MRS Online Proceedings Library Archive, 66.

18. Readey, W. (1987). Specific materials science and engineering education. MRS bulletin, 12 (4), 30-33.

19. Readey, W. (1990). The response of ceramic engineering education to the changing role of ceramics in industry and society. The changing roles of ceramics in society: 26,000 BP to the present, 5, 343-378.

20. Surendranathan, O. (2014). An introduction to ceramics and refractories. London; New York, NY: CRC Press.

21. Tripathi, A., \& Jain, S. (2016). Make in India: new mantra for economy growth. Hail: University of Hail.

22. Wilson, H. (1925). Notes on ceramic engineering education. Journal of the American ceramic society, 8 (10), 519-526. 